\title{
Petroleum Depletion Scenarios for Australian Cities
}

\section{Introduction}

This paper outlines what are the likely global 'events' that peak oil could induce in our highly globalised world including supply disruption, volatility in prices and progressive price rises. All these will impact on our cities. We then pose three indicative development scenarios and assess them as a risk management exercise to examine the relative vulnerability of urban development scenarios and what pattern of development will provide the greatest opportunity for responding to this challenge. Finally a 'glimpse of the future in 2040' is presented to show how the combination of new technology and good urban planning can enable us to make better cities in the future.

\section{Background}

Peak oil is a contested issue. When a barrel of oil reached $\$ 140$ in mid 2008, the world began to remember those who had been predicting a global peak for over 30 years since the first oil shocks began in the 1970's. The science of how any non-renewable resource can be exploited suggests its production cycle will follow a bell curve with a 'peak' roughly at the halfway point. World supplies of conventional oil probably peaked in 2008 and have begun to decline at between $3 \%$ and $6 \%$ per year (Aleklett 2009).

The availability of unconventional oil from deep sea reserves and from petroleum resources like tar sands and shale oil will mean that the world can provide some replacements but at a significant cost and, within a decade they are likely to peak(Zittel \& Schindler 2007; Robelius 2007; Aleklett et al 2009; Campbell 2009),. The world of cheap oil appears to be over. This is a serious discontinuity from previous city and regional economic development eras which were based around cheap fuel for transport.

The peak oil issue is a global one and no place is immune from its impacts. There are only 14 countries that export more oil than they import, Australia is no longer one of these. With its domestic oil production having peaked in 2000 and declining at $11 \%$ per year, Australia is now an oil importer (ACIL Tasman 2008). In June 2009 we imported $45 \%$ of oil needs and this gap is projected to grow rapidly at a time when global supplies are tighter and tighter.

The scenarios outlined in this document will provide the basis for understanding peak oil, what are the risks and opportunities with peak oil, and what actions are suggested for Australian cities in the short term and the long term.

There will be different impacts depending on the level of vulnerability to oil in different cities and within cities. On a global scale the differences between cities in their oil consumption per capita is huge. Kenworthy et al (2001) have collected data on 84 cities comparing the amount of transport fuel per capita. Australian cities are twice as vulnerable as most European cities. In cases like Barcelona, Singapore, Hong Kong and Tokyo (which are all around the same 
or at higher income levels than Australian cities) they are four to five times less vulnerable to transport fuel issues related to peak oil.

Recent data from Kenworthy (pers com 2010) shows that most cities analysed in the global sample have decreased in their transport fuel use per capita between 1995 and 2005; however Australia cities all increased to 2005 but since then an interesting phenomenon has been a consistent decrease in car use per capita and dramatic increase in public transport that bodes well for a transition to reduced fuel vulnerability (Newman and Scheurer; 2010; Stanley, 2010).

Within cities similar variations can be found as between cities. The City of Sydney uses one tenth of the transport fuel used by outer suburbs in Sydney on a per capita basis (Trubka, Newman and Bilsborough, 2008). Dodson \& Sipe (2005 and 2006) examined each Australian city in terms of vulnerability to oil price increases and the ability to repay mortgages. In this remarkably prescient study, which was done before the global financial crisis (GFC), they found that the car dependent residents of outer suburbs that are poorly serviced by public transport are highly vulnerable to the combination of high fuel prices and mortgage debt. This was clearly experienced on a practical level by thousands of families across Australian cities.

Across Australia there is a growing awareness of the need to respond to peak oil. Mostly this is coming from local governments like Gold Coast, Maribynong and Lake Macquarrie though the Queensland Government has included oil vulnerability in the SEQ Plan and it is required to be considered in all local government strategic plans (Newman, McCarthy, Boyle, Wight, 2010). One of the reasons that peak oil has not been included in planning systems in Australia is that governments are not able to imagine the kind of scenarios for the future that could eventuate and are not aware of the kind of risks that could be involved in not addressing peak oil. Thus we will next set out three potential scenarios for what peak oil could do to our cities and how we may need to address these. The approach was used to help the Gold Coast City Council address peak oil (Newman, McCarthy, Boyle, Wight, 2010).

\section{Some likely peak oil 'events'.}

There are three anticipated "events" associated with oil vulnerability that already pose significant risks to Australian cities:

1. Sudden critical supply interruption

This event could be triggered by a sudden major loss of production in a major field (eg. cyclone Katrina, act of war or terrorism) or a similar natural or socio-political event affecting refining or distribution further downstream in the supply chain. The impact of such a disruption will be dependent on the extent and duration of the interruption. For the purposes of this exercise, it is assumed such interruption would seriously disrupt continuity of supply for a period exceeding one month.

2. Volatile price fluctuations and/or intermittent supply disruptions

This event would be triggered by tensions in the supply/demand equation, causing sharp increases in the global price of oil. This 
phenomenon is highly sensitive to (and, in turn, exerts a significant influence on) underlying global economic conditions (Leherrere 2005; Shah 2005; Rupert\& Kane 2006).

\section{Progressive price rises and diminution of supply}

This event is a natural flow-on from the passing of the global peak of oil production and reflects increasing discrepancy between the diminishing capacity of global oil supply and burgeoning underlying global demand (Zittel \& Schindler 2007).

Each of these "events" has a high probability of occurrence at some point. While Australia has not experienced a sudden critical disruption to supply, we have (in the 1970's) experienced temporary shortages resulting in queuing and having some stations temporarily running out of product. The extremely rapid oil price escalation of late 2007/early 2008 up to in the order of $\$ 140 \mathrm{bbl}$ was a response to rapidly-increasing global demand and the constraints of production of "conventional" oil to meet that demand. The subsequent demand collapse associated with the global financial crisis (GFC) no doubt exacerbated by escalating oil prices (Hamilton 2009), resulted in oil prices collapsing to the order of $\$ 30 \mathrm{bbl}$. Since that time, prices have risen back to in excess of $\$ 80 \mathrm{bbl}$. This appears to reflect a supply constraint despite continuing reduced demand in some markets due to the GFC. These fluctuations are already characteristic of "event 2" (Nsouli 2006).

It is speculative to anticipate whether the global financial recovery will strengthen and increase demand to push prices above $\$ 150 \mathrm{bbl}$, or whether the increasing price of oil will trigger further economic turmoil, a recessionary double-dip, and roller-coaster price fluctuations. However, some factors impacting on oil prices can be anticipated.

The influence of the temporary price collapse during the GFC had the effect of deterring investment in "unconventional" oil such as deep sea oil and some alternatives like tar sands and shale oils (IEA 2009). Thus, as conventional oil has peaked, there is a growing concern about reliability of supply, with overall decline currently running between $3 \%$ and $6 \%$ per year. The rate of development of unconventional oil resources is now unlikely to fully offset the inevitable continued depletion of conventional oil sources. This means that it is most likely, irrespective of temporary fluctuations, that there will be an underlying limitation of supply to meet increasing demand, especially from the giant growth economies of India and China. Thus "event 3" is more than likely; it may be inevitable.

The likelihood of "event 1", a sudden critical disruption to supply is considered to be possible though less inevitable than the other two events; however it can be quite devastating if it does happen. The volatility of an "event 2 " has already been demonstrated and has a very high probability of continuing, as it only requires a disruption to supply in some of the most politically vulnerable areas on earth such as the Middle East, Nigeria, or Venezuela. If there is a very large disruption, the more common volatility can turn into a critical supply 
disruption, resulting in a sharp punctuation of a combination of event 2 with an acceleration of event 3 (Newman, McCarthy, Boyle, Wight, 2010).

There is a range of risks associated with those Peak Oil events that can be anticipated over the next twenty years. The severity of these risks depend to a large degree on the nature and pattern of urban development and the infrastructure and services necessary to support that development in terms of where people live, and work, and how and where they access services (Kenworthy pers con 2010; Dodson \& Sipe 2005 and 2006; Trubka, Newman \& Hillsborough 2008). In order to illustrate and evaluate the risks of peak oil, we examine the risk profile associated with three theoretical comparative land use response scenarios for urban development. Each could potentially be adopted by any Australian city as part of its town planning strategy for the next twenty years in response to issues such as climate change and peak oil. These three indicative scenarios enable the possible land development opportunities to be evaluated and assessed in terms of peak oil risk.

From this assessment, a preferred scenario (from a peak oil perspective) can inform the planning process for Australian cities, and mechanisms to effectively manage and mitigate those risks can be developed (Newman, McCarthy, Boyle, Wight, 2010).

\section{Potential Scenarios for a Transition from Peak Oil}

Most cities approaching their future are attempting to reduce their car dependence and their fossil fuel dependence. Different approaches are often adopted and these are discussed in Newman et al (2009) Resilient Cities: Responding to Peak Oil and Climate Change. These approaches have been summarised into three indicative scenarios. For the purposes of this paper, the three scenarios are envisaged for the future, based on where development is directed. The three comparative scenarios are:

- Ruralised Sprawl - where most future development occurs on the urban fringe and is designed to be as self sufficient in food as possible.

- Centralised Concentration - where most future development is directed into the CBD area at very high intensities.

- Decentralised Concentration - where most future development is directed into a number of centres distributed along transit routes, in medium density, mixed use centres, featuring green technology and green buildings with significant landscaping.

The three options are, to some degree, able to be adopted in part, and a preferred scenario will be derived from desirable elements of each.

\section{Ruralised Sprawl}

This option is the most consistent with the present fringe development process whereby the majority of development is in greenfields subdivisions. The exception from the current trend is that developments are regulated to 
provide much greater self sufficiency in food production (Newman, Beatley \& Boyer 2009; Holmgren 2005). This scenario is one that is favoured by a substantial group of people addressing peak oil who see that the basic agricultural system which is largely based on oil is likely to + experience significant problems. The large blocks and open space that are available in fringe development is therefore seen as being a resource to enable intensive urban agriculture to flourish. All waste water is treated and recycled back into the food production system, and there are community-based composting facilities for each area. Food co-operatives are established to help provide information and technical support to all who move into the area and to help market the produce. Significant employment related to this agricultural activity is developed.

The problem with this model is that it occupies very large land areas (effectively suburbanising the whole fringe area very quickly) and it does not address the transport issues of the area. The typically low densities of the suburban area mean that it is not viable for public transport, walking and cycling to major urban services such as major employment centres, schools, shopping, and other services. The development remains very car dependent. Thus, under most peak oil events, the economy of such areas remains extremely vulnerable. This happened in the United States when the oil price reached $\$ 140 / \mathrm{bb}$ and whole areas of ruralised settlements were abandoned.

As set out below there are significant costs involved in this option as a result of the inability to provide infrastructure and services for such lifestyles. There is also no way of requiring urban agriculture to be the main pursuit of those living in the area.

If an eco-village co-operative were formed with the intention of creating a more self sufficient agricultural-oriented community, then such options become more useful and viable. Food self-sufficiency and eco-village cooperative establishment is likely to remain a partial option in the future, especially as a complement to the other development pattern scenarios. As cities are designed to provide opportunities other than agriculture, local food self-sufficiency is never likely to be the main function of a city region, even under extreme disruptions. As discussed in Resilient Cities [reference], even in Havana, which implemented a strong urban agriculture program after the sudden disruption due to oil supply cuts after the fall of the Soviet Union in 1989 , the city remains largely non-agricultural in jobs, services and economy, despite being $40 \%$ self-sufficient in food. Havana remains a city that is largely non car-dependent. This is its main strategy that enables it to survive in a world of oil constraints.

\section{Centralised Concentration}

The opposite of the first option is to direct all new development into high density housing around the CBD (Newman, McCarthy, Boyle, Wight, 2010). This would need to reclaim relatively underutilised areas near to the city and would at least duplicate the number of high rise buildings that are presently in 
most CBDs. The advantages of this option are that it would more effectively utilise much of the infrastructure presently available in the area, it would be close to where most of the employment and many of the services are already provided, and hence it would save considerably on oil consumption and costs.

The disadvantage is that the area would be so intensively developed it would not enable the city to assist those already living in outer suburbs which are the most vulnerable areas of the city.

Centralised concentration would also not facilitate the deployment of emerging decentralised green technologies such as photovoltaics, localised water and waste systems, as they tend to work best distributed across small dense urban centres rather than being concentrated in high density city centres. It would also be very hard to landscape in the productive way of producing food and providing relief to the built form that is more possible in the decentralised concentration option.

There is little doubt that there will be an increasing demand for living and working in this highly centralised way under the increasing influence of peak oil, hence some centralised concentration development must be accommodated and facilitated. However, it is probable that any Australian city basing its future solely on high-rise buildings is likely to experience political resistance and may not be able to fully adapt to a resilient post-oil city form as envisioned by many commentators.

\section{Decentralised Concentration}

The third option enables the city to develop along corridors of highly efficient transit in the form of medium density centres (Newman, McCarthy, Boyle, Wight, 2010). These Transit Oriented Developments are similar to the pattern of life desired in most contemporary inner city areas of Australian cities. The localised access to goods, services and employment would result in a halving in the proportion of car use by people living in the area as they are able to use public transport much more as well as having options in walking and cycling. Where driving is still regarded as the most effective transport mode, the trips are generally much shorter. Under most risk events, the possibility of managing reductions in oil use becomes much more feasible due to reduced car-dependence.

These distributed sub-centres can then provide opportunities to many in outer suburbs to access major urban amenities and services. The centres themselves develop in the nature of small cities in the suburbs and will become activity nodes for the adapted public transport system to focus. Thus bus linkages to the train stations and its associated TOD functions can be provided serving the natural catchments throughout the suburbs, providing all people in the surrounding community with much greater and less cardependent access opportunities.

The centres will provide opportunity for incorporating new green technology such as PV cells on roofs, highly energy and water efficient buildings with 
smart metering, plug-in electric vehicles that can help store the renewable energy produced in the area, water sensitive urban design and high efficiency recycling. These technologies seem to work best when distributed into a series of decentralised centres rather than just one centre or, the worst of all, scattered and fragmented land uses. Green infrastructure is now being developed for zero carbon, zero net water and zero waste developments in demonstrations across Australia (see Sustainability Victoria's Armstrong Creek) and across the globe (eg Masdar in UAE) outlined in Newman, Beatley and Boyer (2009).

These centres can also be the places that are landscaped in new and more sustainable ways through green roofs and green walls that bring nature into, around and over the whole development. This reduces the heat island effect, makes buildings more energy efficient reduces water pollution from run-off, and is highly attractive for residents due to its natural qualities. Some of this greening can be productive as "edible" landscapes. This greening of an urban development is much easier to do with medium density developments than with high rise and single detached housing.

As well as the many physical planning advantages to this scenario, the Polycentric City has also many cost advantages as demonstrated in Trubka, Newman and Bilsborough (2010).

\section{Risks Associated with Urban Development Scenarios}

It is possible to assess the risks to Australian cities now emerging as a result of peak oil. For the purposes of this paper, Table 1 sets out a risk scoring matrix as used by the Gold Coast City Council in assessment of risk according to combinations of likelihood and severity of consequences.

Table 1 - Likelihood Descriptor and Risk Scoring Matrix

\begin{tabular}{|c|c|c|c|c|c|}
\hline \multirow[t]{2}{*}{ Likelihood } & \multicolumn{5}{|l|}{ Consequence } \\
\hline & $\begin{array}{c}\text { Insignificant } \\
1\end{array}$ & $\begin{array}{l}\text { Minor } \\
2\end{array}$ & $\begin{array}{c}\text { Moderate } \\
3\end{array}$ & $\begin{array}{c}\text { Major } \\
4\end{array}$ & $\begin{array}{c}\text { Catastrophic } \\
5\end{array}$ \\
\hline $\begin{array}{l}\text { A (Almost } \\
\text { certain) } \\
10 \text { occurrences } \\
\text { in every year }\end{array}$ & $\mathbf{H}$ & H & $\mathbf{E}$ & $\mathbf{E}$ & $\mathbf{E}$ \\
\hline $\begin{array}{l}\text { B (Likely) } \\
1 \text { occurrence } \\
\text { in every year }\end{array}$ & M & $\mathbf{H}$ & $\mathbf{H}$ & $\mathbf{E}$ & $\mathbf{E}$ \\
\hline $\begin{array}{l}\text { C (Possible) } \\
1 \text { occurrence } \\
\text { in every } 5 \\
\text { years }\end{array}$ & $\mathbf{L}$ & $\mathbf{M}$ & H & $\mathbf{E}$ & $\mathbf{E}$ \\
\hline $\begin{array}{l}\text { D (Unlikely) } \\
1 \text { occurrence } \\
\text { in every } 10 \\
\text { years }\end{array}$ & $\mathbf{L}$ & $\mathbf{L}$ & $\mathbf{M}$ & H & $\mathbf{E}$ \\
\hline
\end{tabular}




\begin{tabular}{|l|l|l|l|l|l|}
\hline $\begin{array}{l}\text { E (Rare) } \\
1 \text { occurrence } \\
\text { in every } 50 \\
\text { years }\end{array}$ & L & L & M & H & H \\
\hline
\end{tabular}

E: Extreme Risk; immediate action required

H: High risk; senior management attention required

M: Medium risk; management responsibility must be specified

L: Low risk; manage by routine procedures [Source Gold Coast City Council Risk Management Policy]

Table 2 sets out the a summary of the relative likelihood of each of the three peak oil 'events' occurring, as well as the general nature of the risks to Australian cities associated with each event for each of the three indicative development scenarios examined (Newman, McCarthy, Boyle, Wight, 2010).

Those risks can be further examined in relation to vulnerable urban sectors including the community, business operations and transport. The likely nature and severity of consequences and impacts on those sectors are assessed by identifying the vulnerability of oil dependent elements and processes in each sector, the critical importance of those elements and processes, and the degree to which those elements and processes would be affected by the identified risks. By matching the likelihood of each risk to the likely severity of the consequences, the level of risk can be ascertained (as per the risk scoring matrix shown at Table 1). Table 2 also indicates a notional assessment of the severity of consequences or impacts and the resultant levels of associated risk for each "event" under the three development scenarios.

Table 2 - Likelihood and nature of risks associated with each 'event'.

\begin{tabular}{|c|c|c|c|c|}
\hline \multirow[t]{2}{*}{ Event } & \multirow[t]{2}{*}{ Likelihood } & \multicolumn{3}{|c|}{ Nature of Associated Risks (severity of consequences / risk level) } \\
\hline & & $\begin{array}{l}\text { Scenario } 1 \\
\text { Rural Sprawl }\end{array}$ & $\begin{array}{l}\text { Scenario } 2 \\
\text { Centralised } \\
\text { Concentration }\end{array}$ & $\begin{array}{l}\text { Scenario } 3 \\
\text { Decentralised } \\
\text { Concentration }\end{array}$ \\
\hline \multirow{4}{*}{$\begin{array}{l}\text { Sudden } \\
\text { critical } \\
\text { supply } \\
\text { interrupt- } \\
\text { tion }\end{array}$} & \multirow[t]{4}{*}{$\begin{array}{c}\text { C } \\
\text { (possible) }\end{array}$} & $\begin{array}{l}\text { No available public } \\
\text { transport. } \\
\text { (moderate impact / high } \\
\text { risk) }\end{array}$ & \multicolumn{2}{|c|}{$\begin{array}{l}\text { Public transport systems unable to cope with } \\
\text { sudden mode shift. } \\
\text { (minor impact / medium risk) }\end{array}$} \\
\hline & & $\begin{array}{l}\text { Limited fuel available for } \\
\text { dispersed economic } \\
\text { activity } \\
\text { (major impact / extreme } \\
\text { risk) }\end{array}$ & \multicolumn{2}{|c|}{$\begin{array}{l}\text { Sharply-constrained access to goods } \\
\text { transported by road and/or produced by oil- } \\
\text { vulnerable processes. } \\
\text { (moderate impact / high risk) }\end{array}$} \\
\hline & & $\begin{array}{l}\text { Inaccessibility to } \\
\text { services. } \\
\text { (major impact / extreme } \\
\text { risk) }\end{array}$ & $\begin{array}{l}\text { Areas outside the } \\
\text { CBD highly } \\
\text { dysfunctional } \\
\text { (moderate impact / } \\
\text { high risk) }\end{array}$ & $\begin{array}{l}\text { Areas beyond } \\
\text { immediate catchment } \\
\text { of centres highly } \\
\text { dysfunctional. } \\
\text { (minor impact / } \\
\text { medium risk) }\end{array}$ \\
\hline & & \multicolumn{3}{|c|}{$\begin{array}{l}\text { Emergency and essential services constrained } \\
\text { (minor impact / medium risk) }\end{array}$} \\
\hline Volatile & & Inability to plan and & Inability to plan and & Inability to plan and \\
\hline
\end{tabular}




\begin{tabular}{|l|c|l|l|l|}
\hline $\begin{array}{l}\text { prices } \\
\text { and } \\
\text { intermit- } \\
\text { tent } \\
\begin{array}{l}\text { supply } \\
\text { disruption }\end{array}\end{array}$ & $\begin{array}{l}\text { A } \\
\text { (almost } \\
\text { certain) }\end{array}$ & $\begin{array}{l}\text { sustain transition to the } \\
\text { necessary degree of } \\
\text { local self-containment } \\
\text { and self-reliance, } \\
\text { creating hardship. } \\
\text { (minor impact / high risk) }\end{array}$ & $\begin{array}{l}\text { sustain transition to } \\
\text { full centralisation of } \\
\text { systems and } \\
\text { exchange, creating } \\
\text { extreme hardship } \\
\text { outside the CBD } \\
\text { (moderate impact / } \\
\text { extreme risk) }\end{array}$ & $\begin{array}{l}\text { sustain transition to } \\
\text { necessary sub-centre } \\
\text { focus and self- } \\
\text { sufficiency, creating } \\
\text { severe disparities } \\
\text { (minor impact / high } \\
\text { risk) }\end{array}$ \\
\hline $\begin{array}{l}\text { Progress- } \\
\text { ive price } \\
\text { rises and } \\
\text { diminu- } \\
\text { tion of } \\
\text { supply }\end{array}$ & $\begin{array}{l}\text { A almost } \\
\text { certain) }\end{array}$ & $\begin{array}{l}\text { Embodied oil } \\
\text { dependence in } \\
\text { underlying systems and } \\
\text { processes inhibits } \\
\text { investment in transition. } \\
\text { (minor impact / high risk) }\end{array}$ & $\begin{array}{l}\text { Embodied infrastructure inhibits investment } \\
\text { shift from oil-dependent to less vulnerable } \\
\text { patterns and modes } \\
\text { (minor impact / high risk) }\end{array}$ \\
\cline { 3 - 4 } & $\begin{array}{l}\text { Limited capacity of } \\
\text { alternative energies and } \\
\text { materials to sustain } \\
\text { current lifestyles and } \\
\text { services. } \\
\text { (minor impact / high risk) }\end{array}$ & \\
\hline
\end{tabular}

As the first vulnerability "event" is "possible" and the others are both "almost certain", the associated risks are typically "high" or "extreme" even where the consequences may be conservatively assessed as "minor" or "moderate". This indicates that such risks should be taken seriously and urgent efforts made for their treatment or management. If further, more detailed, analysis indicates that the consequences or impacts are likely to prove more serious, the level of risks would be even more extreme.

In determining a risk management initiative, it is possible to assess the capacity of each indicative development scenario to respond to or ameliorate those consequences and impacts. Consistent with application of other risk management strategy methodologies, the potential risk treatments are appropriately considered at the various stages of preparedness, prevention, response and recovery. (Newman, McCarthy, Boyle, Wight, 2010)

"Preparedness" for each of the events would involve establishing less cardependent patterns of development, providing a relevant range of less vulnerable transport options and, especially under the ruralised scenario, increased availability of alternative motive energies such as biofuels and/or electricity from renewables.

"Prevention" for each of the events under each of the scenarios would involve a combination of community awareness and vulnerability management planning.

"Response" for each event for the ruralised scenario would rely on a greater focus on localisation and self sufficiency. For the centralised and decentralised concentration scenarios, the response to each event would rely on local area planning and transit-orientation as well as facilitating access by non-motorised transport (walking and cycling). 
"Recovery" for each event for the ruralised scenario would focus on increased local self-reliance and local exchange. For the centralised and decentralized concentration scenarios, the recovery from each "event' would entail greater concentration of a more comprehensive mix of activity and intensity in the centres and maximisation of non-motorised access to those centres from their natural catchments.

The risk analysis shows that ruralised sprawl is at an extreme risk level from a sudden oil supply disruption as it is so car dependent and is at high risk from volatile and progressive price rises. The concentration options are much more able to cope with sudden supply disruptions as they have other options available but both have issues that still need to be addressed.

The worst risk, judged as extreme in our view, is the risk associated with any pattern of development with too much reliance on ruralised sprawl which would be highly vulnerable to a sudden supply interruption and would be severely impacted by both volatile prices and progressive price rises. This pattern of development is highly vulnerable to transport being inadequate, the economy being severely disturbed and local and emergency services being unable to reach all areas.

There are lesser risks (more manageable especially if appropriate plans are prepared and implemented) but nevertheless the risks are "high" for both other scenarios due to the likely inability of public transport to cope with demand as well as issues associated with freight and emergency services.

\section{Preferred Scenario}

From the risk analysis, a preferred scenario would be a further enhancement of the "Decentralised Concentration" which, in planning terms, is called the Polycentric City. The enhancement relates to:

- the provision of high quality transit services with a focus on each centre from its immediate catchment and linking each centre to the next higher-order centre;

- the facilitation of local enterprise to foster localised production and exchange to minimise the growth (and impact) of the transport task for both people and freight; and

- the retrofitting of existing suburbs and occupied acreages beyond the immediate $(3 \mathrm{~km})$ catchments of significant mixed-use centres to become self sufficient but have a better access to jobs and services (in the new TOD centres) other than by car;

This optimised scenario will enable a much higher proportion of people to live in less car dependent areas. Further, it will enable the highly vulnerable suburbs to have more convenient access to local services and jobs in their adjacent TOD centres as well as a much more viable transport system linking them to their nearest major centre. The risks from peak oil are minimised and the opportunities for responding are greater under this scenario (Newman, 
McCarthy, Boyle, Wight, 2010). There is also value in trying to improve local food production that is mostly associated with "Ruralised Sprawl" and to develop a strong core as in the "Centralised Concentration".

\section{Urgency}

An over-riding risk is that oil vulnerability will translate into severe impacts of likely oil depletion "events", compromising any Australian city's liveability long before the measures necessary to reduce that vulnerability are implemented, or for more resilient land use patterns to be put in place.

While pursuit of the preferred scenario proposed does promise to ease vulnerability to the impacts of oil depletion (both cost and limitation of supply), the timeframe needed to transition to such a pattern of development is relatively long. By comparison, it took 17 years to transition from leaded to unleaded petrol even though it was supported by Federal legislation and the technical adjustments were relatively straight-forward.

Even though most current and proposed town planning provisions seek future land use patterns which promise to reduce oil vulnerability, we are unlikely to have the luxury of a short timeframe to respond to some of the anticipated events associated with peak oil. The increase in oil consumption in oil exporting countries and the inevitable depletion of currently dominant giant fields means that progressively less oil will be available on the open market irrespective of current rates of production. The increasing appetite for oil in the emerging economies of India, China and others was already putting a squeeze on supply capacity before the GFC, and will be a critical factor in constraining a global recovery. The price of oil has already risen from the $\$ 30 / \mathrm{bbl}$ at the depth of the GFC to the current level of over $\$ 80$.

As planning schemes and local area plans can only regulate new development and redevelopment, and their implementation is dependent on the rate of development, they are constrained in quickly influencing existing infrastructure and land uses. The lag time before even the most ambitious and progressive planning instruments can change the development pattern paradigm is likely to delay full realisation of alternative land use scenarios for decades. To avoid the worst impacts of oil vulnerability, planning provisions will need to be complemented by more pro-active intervention by all levels of government, industry and the community.

Any detailed oil vulnerability risk management plan must respond to this urgency, and provide a comprehensive and timely balance of measures to effectively manage the potential rate of decline of oil availability and potential price signals through progressive reduction in both oil-dependence and demand.

\section{Economic Implications}

The response to any change in Australian cities is usually that it will cost more and hence will be difficult. The need to respond to peak oil is however 
becoming an economic imperative as indicated by the oil-price induced Global Financial Crash and other papers in this edition. Our analysis of the economics of urban form changes that are required would suggest that they should be done whether or not the price of oil and cuts in oil supply impinge on the future, though we expect they will and hence the economic implications will be even more severe. In Table 3 below the summary of an economic study (Trubka, Newman and Bilsborough, 2010) is provided that examined the extra costs associated with continuing urban sprawl at the fringe (ruralised sprawl) with redevelopment in TODs (decentralized concentration).

Table 3: Estimated Development Costs for a Decentralised Concentration Compared to Ruralised Sprawl Development per Dwelling

\begin{tabular}{|c|c|c|c|}
\hline & $\begin{array}{l}\text { Decentralised } \\
\text { Concentration }\end{array}$ & $\begin{array}{c}\text { Ruralised } \\
\text { Sprawl }\end{array}$ & Difference \\
\hline \multicolumn{4}{|l|}{ Infrastructure Costs } \\
\hline Roads & $\$ 5,086$ & $\$ 30,379$ & $\$ 25,292$ \\
\hline Water and Sewerage & $\$ 14,748$ & $\$ 22,378$ & $\$ 7,630$ \\
\hline Telecommunications & $\$ 2,576$ & $\$ 3,712$ & $\$ 1,136$ \\
\hline Electricity & $\$ 4,082$ & $\$ 9,697$ & $\$ 5,614$ \\
\hline Gas & & $\$ 3,691$ & $\$ 3,691$ \\
\hline Fire and Ambulance & & $\$ 302$ & $\$ 302$ \\
\hline Police & & $\$ 388$ & $\$ 388$ \\
\hline Education & $\$ 3,895$ & $\$ 33,147$ & $\$ 29,252$ \\
\hline Health (Hospitals, etc.) & $\$ 20,115$ & $\$ 32,347$ & $\$ 12,233$ \\
\hline Total Infrastructure & $\$ 50,503$ & $\$ 136,041$ & $\$ 85,538$ \\
\hline \multicolumn{4}{|l|}{ Transport Costs $^{1}$} \\
\hline Transport \& Travel Time & $\$ 206,542$ & $\$ 342,598$ & $\$ 136,056$ \\
\hline Roads \& Parking & $\$ 46,938$ & $\$ 154,826$ & $\$ 107,889$ \\
\hline Externalities & $\$ 2,220$ & $\$ 9,705$ & $\$ 7,486$ \\
\hline Total Transport & $\$ 255,700$ & $\$ 507,130$ & $\$ 251,430$ \\
\hline
\end{tabular}

\footnotetext{
${ }^{1}$ Transport costs are calculated as operating costs and thus are a function of vehicle kilometers traveled (VKT) and patronage.
} 


\begin{tabular}{|c|l|l|l|}
\hline Greenhouse Gas Cost & & & \\
\hline Offset Cost $(\$ 25 / \mathrm{t})$ & $\$ 2,500$ & $\$ 5,400$ & $\$ 2,900$ \\
\hline $\begin{array}{c}\text { Social Cost }(\$ 215 / \mathrm{t})- \\
\text { NOT INCLUDED IN } \\
\text { TOTAL }\end{array}$ & $\$ 21,500$ & $\$ 46,440$ & $\$ 24,940$ \\
\hline Total Greenhouse & $\mathbf{\$ 2 , 5 0 0}$ & $\mathbf{\$ 5 , 4 0 0}$ & $\mathbf{\$ 2 , 9 0 0}$ \\
\hline Physical Activity Costs & & & \\
\hline Healthcare Cost & & & $\$ 4,230$ \\
\hline Productivity Loss & & $\$ 34,455$ \\
\hline Total Activity Costs & & $\mathbf{\$ 6 8 7 , 3 1 6}$ & $\mathbf{\$ 3 7 8 , 5 5 3}$ \\
\hline Total & $\mathbf{3 0 8 , 7 0 2}$ & & $\mathbf{3 8 , 6 5}$ \\
\hline
\end{tabular}

The costs display the differential cost streams associated with the two alternative development paths. Many of the estimates were made conservatively: infrastructure costs may vary depending on excess capacity levels and area-specific requirements; greenhouse gas costs are dependant on a price for carbon and will go up or down accordingly; and health savings are dependant on the types of mode-specific infrastructure put into place combined with incentive schemes and public education. Furthermore, it should be noted that the infrastructure costs are up-front costs that require payment upon initial development. The transport, greenhouse gas, health costs and productivity losses are present values calculated over a 50-year period and could be considered as operating costs of the respective types of development, except for the health and productivity costs which were calculated as foregone benefits by choosing to develop on the fringe (hence them being omitted from the inner-city and fringe cost streams).

Nevertheless, the size of the different costs does provide some perspective on the overall costs of ruralised sprawl and the savings if a less oil-vulnerable urban form was adopted. Other studies (summarised in Trubka et al 2010) have indicated the substantial costs of infrastructure and transport, which we too have demonstrated and which should be of considerable concern to cities contemplating a future with plans to continue major greenfields development. However, we can now see that two of the newer parameters relating to urban development - the social costs of greenhouse and health-related productivity due to greater walkability - add another

\footnotetext{
${ }^{2}$ The Cumulative Economic Impact Statement does not include the social cost of carbon (SCC) from transport greenhouse gas emissions. It is assumed that abatement, being the more cost-effective option, would be preferred over sustaining the harm or global warming; however, without proper policy measures put in place the social costs will continue to surmount.
} 
substantial cost rationale to the value of redevelopment where considerably more active transport modes are built-in to the urban form. The productivity gains are alone quite considerable and appear to be around a $6 \%$ increase in workforce productivity due to less absenteeism and more on-job productivity.

\section{A Glimpse of the Future in 2040}

In order to grasp the opportunities that an appropriate and timely response to Peak Oil presents, a glimpse into the potential future of a typical Australian city is provided - if the city does everything right. It shows some direction for how the city and its hinterland can respond to creating a thriving, sustainable and resilient post peak-oil city (Newman, McCarthy, Boyle, Wight, 2010).

By 2040 the world will have to have reduced its oil consumption by at least $50 \%$. The Australian city has shown it can do much better than this...

\section{A Polycentric, transit oriented city with much reduced need to travel.} A series of sub-centres or 'cities in the suburbs' emerge throughout the urban region as new rail lines are opened and extended to link sub-centres and to provide well-serviced nodes as the focus of each sub-centre. These centres provide opportunities for people in the suburbs to shop, reach services, go to the movies, jobs and schools, as well as have a place to meet friends and walk around. They are all linked by good cross suburban bus services, providing a high quality of service to each centre from its natural catchment. The buses all run on natural gas or are plug-in electric buses and provide a high quality service to each centre from its natural catchment. The region is criss-crossed with cycle paths between centres accessing and serving each new centre. The main CBD, as well as each sub-centre, has a walkability plan that enables a constant upgrading of the pedestrian environment. Based on early $21^{\text {st }}$ century comparisons the urban region now has at least $50 \%$ less private vehicle use complemented by a wider range of attractive mobility options.

\section{Supplemented by private Plug in Electric Vehicles that enable 100\% renewably derived power.}

The urban region is surrounded by wind farms and on every rooftop PV cells are drawing on the sun to provide renewable power into the grid - which has been upgraded to provide economical energy storage capacity, smart control systems and smart meters to manage the fluctuations in supply. At each home, shopping centre and business, shared plug-in electric vehicles are parked; each vehicle is part of a program to enable renewable power to be stored and released back into the grid as demand rises during the day. Owners program how much their PEV's can contribute back to the grid knowing that they will earn money from the utility as power is more expensive during peak periods than at night. Quick recharging can be obtained at each sub-centre and from service stations now converted to provide $100 \%$ renewable power and natural gas.

\section{A Highly Eco-efficient City using Renewable Natural Gas for Freight and Industry}


Natural gas has become the fuel for those vehicles that previously used diesel in the old days of oil, but which are not amenable to powering by renewable electricity. Industry also uses natural gas for process heat though the amount needed for manufacturing and production is now reduced by a factor of 4 or 5 due to a myriad of clever eco-efficient technologies. Natural gas was abundant due especially to coal seam gas but in recent years natural gas is being created from $\mathrm{CO}_{2}$ at power stations with the use of giant solar collectors. The natural gas is distributed through pipes and is stored and exported as LNG.

\section{A Biophilic, Beautiful, Cool City with a Strong Sense of Place}

As part of its Climate Change and Peak Oil Strategy the CBD high rise area as well as the intensive mixed-use sub-centres, have become models for reducing the urban heat island effect through landscaping. Every building has green roofs (along with PV's), and green walls that drape across the city and join up with street trees and urban parks. The biodiversity of the city has created a whole new movement of urban bird watchers. New small creeks channel storm water that is slowly released from the biophilic buildings. The city revels in its new identity as one of the greenest cities in the world. The city and most centres in the region doing similar landscaping are $5^{\circ} \mathrm{C}$ cooler than they were in the heat stress days of the early $21^{\text {st }}$ century.

\section{A City that Feeds Itself}

A further extrapolation of the biophilic transformation includes the use of green roofs and walls as well as a proportion of ground level greenspace as "edible urban landscape". The limitation of expansion of the urban footprint affords the protection of valuable ecosystems, the delivery of ecosystem services, nature-based outdoor recreation and, importantly, increasing excellence and capacity in sustainable organic food production. The combination of these initiatives will substantially increase the availability of fresh, local foods and reduce the transport impacts of excessive "food miles".

\section{Conclusions}

Australian cities are vulnerable to peak oil. For that reason alone we should be showing global leadership on this issue. There are real risks that need to be assessed in all land development issues. However it is also an opportunity to address a number of structural issues that can manage the need to reduce carbon and other resources, to reduce car dependence in general, to respond to the new smart and sustainable technologies for energy, water and waste that work best in the decentralized concentration urban form, and the opportunity to create a beautiful biophilic city through intensive greening of all new development. A creative and positive response to the challenges posed by peak oil will therefore help to achieve a range of other urban objectives and yield a better and more resilient urban outcome.

\section{References}

\section{ACIL Tasman, 2008, An Assessment of Australia's Liquid Fuel Vulnerability, Melbourne, at}


http://www.ret.gov.au/energy/energy security/emergency response/liquid fuel emergency/lfe vulnerability/Pages/lfe vulnerability.aspx

Aleklett, Kjell, et al., 2009, "The Peak of the Oil Age: Analyzing the World Oil

Production Reference Scenario IEA World Energy Outlook 2008”, Energy

Policy, in print, full text available at

http://www.fysast.uu.se/ges/en/publications/the-peak-of-the-oil-age-

analyzing-the-world-oil-production-reference-scenario-in-world-.

Campbell, Colin J., 2009, Summary of Oil and Gas Depletion, 28 March 2009.

Regularly updated at http://www.aspo-

ireland.org/index.cfm/page/newsletter.

Dodson, Jago and Sipe, Neil, 2006, Shocking the Suburbs: Urban Location, Housing Debt and Oil Vulnerability in the Australian City, Griffith University, Brisbane,

at http://www.griffith.edu.au/ data/assets/pdf file/0004/48577/urp-rp08dodson-sipe-2006.pdf.

,2008, Unsettling Suburbia: The New Landscape of Oil and Mortgage Vulnerability in Australian Cities, Griffith University, Brisbane, at http://www.griffith.edu.au/ data/assets/pdf file/0003/88851/urp-rp17dodson-sipe-2008.pdf.

Hamilton, James D., 2009a, Causes and Consequences of the Oil Shock of 2007-08, presented at the Brookings Panel on Economic Activity, at http://www.brookings.edu/economics/bpea/ /media/Files/Programs/ES/B PEA/2009 spring bpea papers/2009 spring bpea hamilton.pdf. , 2009b, Oil Prices and the Economic Downturn, testimony prepared for the Joint Economic Committee of the U.S. Congress, 20 May, at http://www.econbrowser.com/archives/2009/05/Hamilton JEC 200905 20.html.

Holmgren, David, 2005, "Retrofitting the Suburbs for Sustainability", CSIRO Sustainability Network Update, no 49E, Adelaide, pp. 1-9, at http://www.bml.csiro.au/susnetnl/netwl49E.pdf. , 2009, Future Scenarios: How Communities Can Adapt to Peak Oil and Climate Change, Chelsea Green, White River Junction. See also http://www.futurescenarios.org/.

Höök, Mikael, Hirsch, Robert L. and Aleklett, Kjell, 2009, "Giant Oil Field Decline Rates and their Influence on World Oil Production", Energy Policy, Vol. 37, Iss. 6, pp. 2262-72. Full text available at http://www.fysast.uu.se/ges/en/publications/giant-oil-field-decline-ratesand-their-influence-on-world.

International Energy Agency, 2009a, The Impact of the Financial and Economic Crisis on Global Energy Investment, IEA Background Paper for the G8 Energy Ministers' Meeting 24-25 May. Executive summary available at http://www.iea.org/Textbase/Papers/2009/G8 investment ExecSum.pdf.

Laharrère, Jean, 2005, Peak Oil and Other Peaks, Presentation to CERN Meeting, 3 October 2005, at http://www.hubbertpeak.com/laherrere/CERN200510.pdf.

Newman, Peter, Boyer, Heather and Beatley, Tim, 2009, Resilient Cities: Responding to Peak Oil and Climate Change, Island Press. 
Newman, Peter, McCarthy, Stuart, Boyle, Sharon, Wight, Wallace, 2010, Gold Coast City Council Peak Oil Desk Top Study, May 2010 unpublished.

Newman P and Scheurer J 2010 The Knowledge Arc Light Rail, PB- CUSP Discussion Paper, Fremantle.

Nsouli, Saleh M., 2006, Petrodollar Recycling and Global Imbalances, International Monetary Fund, March, at http://www.imf.org/external/np/speeches/2006/032306a.htm.

Robelius, Fredrik, 2007, Giant Oil Fields - The Highway to Oil: Giant Oil Fields and their Importance for Future Oil Production, Uppsala University, September 2007, at http://www.fysast.uu.se/ges/en/publications/giant-oilfields-the-highway-to-oil-giant-oil-fields-and-their-importance-for-future-oi.

Ruppert, Michael C. and Kane, Michael, 2006, The Markets React to Peak Oil, From the Wilderness Publications, 2006, at http://www.fromthewilderness.com/members/100406 markets react.shtm l.

Shah, Sonia, 2005, "Peak Oil's Bumpy Plateau", New Matilda, 6 July 2005, at http://newmatilda.com/2005/07/06/peak-oil\%2526\%2523039\%3Bsbumpy-plateau.

Stanley J, 2010, Moving People, Australian Railway Association and Bus Confederation of Australia, Canberra.

Trubka R, Newman P and Bilsborough D (2010) The Costs of Sprawl (Parts 1,2 and 3) Environment Design Guide Nos 83, 84 and 85.

Zittel, Werner and Schindler, Jörg, 2007, Crude Oil: The Supply Outlook, Energy Watch Group, October 2007, at http://www.energywatchgroup.org/fileadmin/global/pdf/EWG Oilreport 10 -2007.pdf. 